Umi Sofiana ${ }^{1}$, Moses Glorino Rumambo Pandin ${ }^{2}$

${ }^{1}$ Faculty of Nursing, ${ }^{2}$ Faculty of Humanitie,

Airlangga University, Surabaya

Dr. Ir. H. Soekarno Street, Mulyorejo District, SBY City, East Java 60115

umi.sofiana-2020@ fkp.unair.ac.id dan moses.glorino@fib.unair.ac.id

\title{
Book Review: Pendidikan Kewarganegaraan: Konsep Dasar KehidupanBerbangsa dan Bernegara di Indonesia
}

Book Title: Pendidikan Kewarganegaraan (KonsepKehidupanBerbangsa dan Bernegara di Indonesia); Author Name: Dr. Drs. Ismail, M.Si and Dra. Sri Hartati, M. Si; Publisher: CV. Qiara Media Publisher; City of publication: Pasuruan; Edition: First printing, 2020; Number of Pages: 365 Pages; ISBN: 78-623-7365-61-7

\section{INTRODUCTION}

The author created this book intending to help students' awareness of civic education's importance . Civic education in higher education provides insight into nationality and can also be a provision for students to face the future.This book was equipped with historical sources of all components in Indonesia, such as historical sources of human rights, insights into the archipelago, and others. Although the information in this book does not include the most recent information, its content is compelling because it comes from reliable sources.Most of them are taken from state laws which are trustworthy and supported with a lot of international theory.

\section{REVIEW}

This book was written to increase the younger generation's knowledge about citizenship, a loss of feeling to love their homeland, and a loss of pride in Indonesia. In addition, the author also realizes the importance of civic education for the nation's next generation. That is what makes the author create this book, which aims to help the younger generation, especially students, to aware of civic education's importance in this life. In order to achieve national aspirations, Indonesian must have competent capabilities. Therefore, this book presented to students as a provision to replace the previous generation and realize Indonesia's ideals.

This book needs to be read by students considering that it contained complete contents regarding each component that a citizen must understand. Each chapter was explained quite 
clearly, such as urgency, history, challenges, and also accompanied by exercises. Unfortunately, the book didn't use the latest information, and the author only includes information that already exists.

Pendidikan Kewarganegaraan: Konsep Dasar Kehidupan Berbangsa dan Bernegara di Indonesia book provides several new knowledge for the readers. This book can help the reader to influence their thoughts because it provides several new pieces of knowledge. In addition, this book is very useful for students to support their learning related to citizenship. The author includes very definite evidence, including the unquestioned laws. The writing style is suitable for students because the word choices are not too difficult. Each chapter material is also presented in order but it is not continuous. Each chapter stands alone with a sequential explanation.

This book still lacks attractive illustrations so the readers can quickly get bored and difficult to understand. The contents of this book are too ordinary because the author only provides material or information without adding case studies that can help readers think critically. Authors should add illustrations as well as case studies to assist the reader's understanding process. However, this book still deserves to be read by students because the contents really help students as the nation's next generation to become a generation that is not blind to the crucial components of their country.

\section{REFERENCE}

1. Ismail, Hartati S. Pendidikan Kewarganegaraan: Konsep Dasar Berbangsa dan Bernegara di Indonesia. $1^{\text {st }}$ ed.Pasuruan: CV. Penerbit Qiara Media, 2020. 357 p.

\section{Writer Biography}

Dr. Drs. Ismail, M. Si was born on May 27, 1969 in South Sulawesi. He is a lecturer at the Governmental Political Study Program, Institute of Domestic Government (IPDN). He also serves as dean at the FMP of the Bogor Institute of Internal Administration. Apart from being a lecturer, he is also active in research related to increasing the capacity of local governments, subdistricts, DPRD, and others. He also created several works. 
Dra. Sri Hartati, M. Si was born on February 4, 1970 in Jambi. He is a permanent lecturer at the Institute of Domestic Government (IPDN). Not only that, he is active in government applied research and community service activities. 